\title{
Approche de la variabilité des systèmes de production lithique des industries du paléolithique inférieur et moyen : chronique d'une variabilité attendue
}

Eric Boëda

\section{OpenEdition}

\section{Journals}

Édition électronique

URL : https://journals.openedition.org/tc/685

DOI : $10.4000 /$ tc. 685

ISSN : 1952-420X

Éditeur

Éditions de l'EHESS

Édition imprimée

Date de publication : 1 novembre 1992

ISSN : 0248-6016

\section{Référence électronique}

Eric Boëda, «Approche de la variabilité des systèmes de production lithique des industries du

paléolithique inférieur et moyen : chronique d'une variabilité attendue », Techniques \& Culture [En ligne], 17-18 | 1992, mis en ligne le 10 janvier 2006, consulté le 29 septembre 2022. URL : http:// journals.openedition.org/tc/685; DOI : https://doi.org/10.4000/tc.685

Ce document a été généré automatiquement le 29 septembre 2022

Tous droits réservés 
Approche de la variabilité des systèmes de production lithique des industries du paléolithique inférieur et moyen : chronique d'une variabilité attendue

Eric Boëda 